\title{
Biodiversity of Pests of Rice in Odisha
}

\author{
Prakash Chandra Rath, Lotan Kumar Bose*, Hatanath Subudhi, \\ Srikanta Lenka and Nitiprasad N. Jambhulkar
}

ICAR-National Rice Research Institute Cuttack-753006, India

*Corresponding author

A B S T R A C T

\section{Keywords}

Biodiversity, Pests, Rice, Stem borer, Green leaf hopper, Crop cultivation

Article Info

Accepted: 05 February 2020 Available Online: 10 March 2020
Major Rice growing district of Odisha was studied pest diversity. Most of the paddy farmers face huge economic losses in paddy cultivation due to damage by insect pest. This study aims to enlist major rice pests that are present in rice fields of all major rice growing district of Odisha are explained in this detail report.

\section{Introduction}

Rice is the most important field crop and a good example of changing insect pest scenario in Odisha. After the green revolution in India, there has a constant increase in the number of insect pests, and a concomitant shift in their pest status, diversity and spread (Sain and Prakash, 2008).

It is interesting to mention that the insect pest scenario of the crop gradually changing with gradual changes in crop cultivation practices and climate change, especially the higher temperature. Several major pests have become minor and many minor pests attained the status of major pests. There are records of many new pests shifting the host and also some invasive pests due to change their habitat (Prakash, 2013). There are many good examples of such changing insect pest scenario in rice crops.

At present the major insect pests of Rice in Odisha are as follows: Yellow stem borer (YSB): Scirpophaga incertulas Walker, Swarming caterpillar: Spodoptera mauritia Boisd., Asian rice gall midge (ARGM): Orseolia oryzae Wood Mason, Brown plant hopper (BPH): Nilaparvata lugens Stall., White backed plant hopper (WBPH): Sogatella furcifera Horvath, Rice hispa (RH): 
Dicladispa armigera Oliv., Rice bug/ Gundhi bug/ Ear head bug: Leptocorisa acuta Thunb., Green leaf hopper(GLH):Nephotettix virescens Dist., Leaf folder (LF): Cnaphalocrocis medinalis Guen., Rice case worm: Nymphula depunctalis Guenee, Termite: Microtermes obesi Holm., Rice thrips: Baliothrips biformis Bagnall, Rice mealy bug: Brevennia rehi Lindinger. The infestation status of some important insect pests of rice in Odisha are given as follows.

$\begin{array}{lll}\text { Stem Borer } & : & \text { Severe } \\ \text { Gall midge } & : \text { Severe } \\ \text { Brown plant hopper } & : \text { Medium } \\ \text { Green leaf hopper } & : \text { Severe } \\ \text { Leaf folder } & : \text { Medium } \\ \text { White backed plant } & : \text { Low } \\ \text { hopper } & : \\ \text { Cut worm } & \text { : } \\ \text { Hispa } & \text { Low } \\ \text { Gundhi bug } & \text { Low }\end{array}$

The rice grain yield is reduced significantly due to attack of different insect pest and diseases at different stages of crop growth. Farmers are confused to take control measure at the time of infestation. To solve this problem, economic threshold levels (ETL) for important insect pests and diseases of rice have been worked out. On the basis of ETL farmer can take decision to control the insect pest and diseases in their field by chemical means.

\section{Insect pest and Economic threshold diseases level (ETL)}

$\begin{array}{ll}\text { Stem borer } & : \begin{array}{l}10 \% \mathrm{DH}, \text { or } 1 \mathrm{egg} \\ \text { mass or } 1 \mathrm{moth} / \mathrm{m}^{2}\end{array} \\ \text { Gall midge } & : \begin{array}{l}5 \% \text { at active tillering } \\ \text { stage }\end{array} \\ \mathrm{BPH} \text { and WBPH : } \begin{array}{l}10 \text { insect/hill at veg. } \\ \text { and } 20 / \mathrm{hill} \text { at late }\end{array} & \begin{array}{l}\text { stage } \\ \text { Green } \quad \text { Leaf }:\end{array} \\ & 2 \text { insect/hill in } \\ \text { Hoppper } & \text { tungro, Endemic area }\end{array}$

and 20-30/hill for other areas

\begin{tabular}{|c|c|}
\hline Leaf Folder & $\begin{array}{l}3 \text { damaged leaf/hill } \\
\text { post active tillering } \\
\text { stage }\end{array}$ \\
\hline Cut worms & : 1 leaf/hill \\
\hline Gundhi bug & : 1 nymph or adult/hill \\
\hline Rice Blast & $\begin{array}{ll}5-10 \% & \text { disease } \\
\text { severity } & \end{array}$ \\
\hline Brown spot & : $10 \%$ disease severity \\
\hline Sheath blight & $\begin{array}{l}3-5 \% \text { tillers affected } \\
\text { with } 3-4 \% \text {, disease } \\
\text { on lower leaves }\end{array}$ \\
\hline Sheath rot & $\begin{array}{l}3-5 \% \text { incidence on } \\
\text { panicle bearing tillers }\end{array}$ \\
\hline $\begin{array}{l}\text { Bacterial leaf } \\
\text { blight }\end{array}$ & $: \begin{array}{l}5-10 \% \text { leaf area } \\
\text { damaged }\end{array}$ \\
\hline $\begin{array}{ll}\text { Rice } & \text { Tungro } \\
\text { Disease } & \end{array}$ & $\begin{array}{l}: 1-2 \\
\text { plants } / \mathrm{m}^{2}\end{array}$ \\
\hline
\end{tabular}

The rice stem borers having wide distribution in almost all the rice growing countries and constitute an economically important group of pests. In Odisha, there are five predominant rice stem borer species as follows.

\begin{tabular}{|c|c|c|}
\hline $\begin{array}{l}\text { Yellow stem } \\
\text { borer (YSB) }\end{array}$ & & Scirphophaga incertulas \\
\hline $\begin{array}{l}\text { White stem } \\
\text { borer (WSB) }\end{array}$ & $\therefore$ & Scirphophaga innonata \\
\hline $\begin{array}{l}\text { Pink stem } \\
\text { borer (PSB) }\end{array}$ & . & Sesamia inference \\
\hline $\begin{array}{l}\text { Stripped stem } \\
\text { borer (SSB) }\end{array}$ & 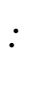 & Chilo polychrysus \\
\hline $\begin{array}{lr}\text { Dark } & \text { headed } \\
\text { stem } & \text { borer } \\
\text { (DSB) } & \end{array}$ & $\therefore$ & Chilo suppressalis \\
\hline
\end{tabular}

Rice gall midge, Orseolia oryzae remained a wide spread pest up to 1990 s with emergence of six biotypes, causing serious losses in new areas like Bihar, North East state of Manipur in addition to some traditional areas of Odisha, Andhra Pradesh, Madhya Pradesh and Kerala. Suspected biotype occurrence in two places like Warangal in A.P. and Cuttack 
in Odisha was observed during 1955 (Khan and Murthy, 1955). Four biotypes of gall midge exist in India (Kalode and Bentur, 1989) and recently one more biotype from Kerala state capable of damaging the newly identified donors has been reported (Annonymous, 1994).

\section{Gall midge Locations in India} Biotypes

GMB1

GMB2

GMB3

GMB4

GMB5

Warangal, Raipur, Sambalpur and Madurai

Cuttack and Bhubaneswar

Ranchi and Manipur

Sakoli and Srikakulam

Moncompu

Cut worms are becoming serious in many rice growing areas in the east part of the country. Recently severe damage was reported to 30,000 ha of rice in Assam. Since last few seasons, some of the cut worms like, the climbing cutworm, Mythimna albistigma Moore; ear cutting caterpillar Mythimna seperata Walker and leaf eating caterpillar Spodoptera compta Moore, have been regularly occurring in coastal Andhra Pradesh and the Eastern States including Odisha.

The most important cut worms of the rice crop in India is the rice swarming caterpillar Spodoptera mauritia which was considered as minor pest, now becoming major pest due to climate change. The rice swarming caterpillar, has acquired a status of major pest in Odisha, Bihar, Chhatisgarh and Jharkhand during kharif, 2007-09, 2011-12 and devastated paddy crop in early stage (Prakash et al., 2009, Tanwar et al., 2010 and Prakash, 2013). There was a severe outbreak of rice swarming caterpillar in Western Odisha particularly in districts of Sonepur, Bolangir, Sambalpur, Bargarh and Kalahandi in kharif 2008. Swarming caterpillar attack was first reported at Birmaharajapur block of Sonepur district during June, 2008 and then it spread to
Tarava, Sonepur and Binica blocks. However, the rice crop recovered from the damage due to timely application of DDVP and endosulfan insecticide. The Agalpur block of Balangir district, Padmapur block of Bargarh district and Banipadar village of Kalahandi were severely affected by this pest during kharif 2008. The local climatic condition mainly heavy rainfall, nearby hills, forest coverage and river might have contributed to the pest outbreak (Rath et al., 2014).

The rice hispa, Dicladispa armigera was a minor pest earlier has assumed the status of major pest in irrigated paddy field, lowland boro rice cultivation in West Bengal, Assam and North-East Indian states. In Odisha, hispa outbreak was reported at Bainsia, Ballav and Ambabati grampanchayat of Gondia block of Dhenkanal District during $1^{\text {st }}$ week of September, 2008. About 1300 ha area was affected covering varieties like Annapurna, Pooja, Swarna and Lalat. Besides climatic factors, effect of vast areas of swampy land nearby and unweeded fields might have contributed to hispa outbreak in that locality (Rath et al., 2014).

In rice, increasing incidence of mealy bugs were observed in states of Odisha, Jharkhand and West Bengal during last five year. Severe drought, bad drainage and poor soil increase the mealy bug infestation. Primarily the pest is reported to cause heavy damage in upland rice due to dry atmosphere.

The rice case worm, Nymphula depunctalis (Guen.) is a problem in lowland and semideepwater rice ecology and an important pest in vegetative stage in Odisha. Usually this pest occurs in low populations in paddy fields with standing water because of its semi aquatic mode of life cycle. It is found in irrigated and rainfed wet land environments and is more prevalent in rainy season. 
There are other insect pests of regional significance such as gundhi bug and termites. These are major insect pest of upland rice ecology whereas white grubs are problems in specific upland hill rice.

\section{References}

Anonymous, 1994. Progress report 1994. All India Coordinated Rice Improvement programme. Directorate of rice Research, Hyderabad. Pp.48.

Kalode, M. B. and Bentur, J. S. 1989. Characterization of Indian rice gall midge, Orseolia oryzae Wood-Mason (Cecidomyiidae: Diptera). Insect science and its application, 10: 219-224.

Khan, M. Q. and Murthy, D. V. 1955. Some notes on the rice gall fly, Pachydiplosis oryzae Wood-Mason. J. Bombay Nat. Hist. Soc., 53: 97-102.

Prakash, A., S. Sasmal, J. Rao and Singh, N. K. 2009. Changing climate and rice pest scenario in India. Presented in national conference on Pest Bio-diversity in rice and their management under changed climate, organized by AZRA, India and CRRI, Cuttack during 15-16, December, 2009, Abstract No.002.

Prakash, A. 2013. Key note address on "Rice pest and climate change" in National
Symposium on Man, Animal and environmental interaction in the perspectives of modern research, at North Bengal University, Rajarammohanpur, Darjeeling, W.B., 89,March,2013. Pp.3-5.

Rath, P. C., M. Jena, K. S. Behera and Sasmal, S. 2014. Pest outbreaks and resurgence in rice ecosystem in OdishaA retrosperct. Lead paper in souvenir, presented in $7^{\text {th }}$ National seminar on Emerging climate change issues and sustainable management strategies, 819, February, 2014 at Dr. M. S. Swaminathan Hall, OUAT, Bhubaneswar. Pp. 20-21.

Sain, M. and Prakash, A. 2008.Changing pest scenario of cereal crops. Presented in National Conference on "Pest management strategies for food security" at IGKV, Raipur on 2-3 May,2008, Souvenir:lead papers. Pp. 27-29.

Tanwar, R. K., A. Prakash, S. K. Panda, N. C. Swain, D. K. Garg S. P. Singh, S. Satya Kumar and Bombawale, O. M. 2010. Rice swarming caterpillar (Spodoptera mauritia) and its management strategies. NCIPM, New Delhi, Technical bulletin: 24. Pp19

\section{How to cite this article:}

Prakash Chandra Rath, Lotan Kumar Bose*, Hatnath Subudhi, Srikanta Lenka and Nitiprasad N. Jambhulkar. 2020. Biodiversity of Pests of Rice in Odisha. Int.J.Curr.Microbiol.App.Sci. 9(03): 566-569. doi: https://doi.org/10.20546/ijcmas.2020.903.066 